\title{
Morphoanatomy of three Indigofera species (Leguminosae-Papilionoideae) in Java, Indonesia
}

\author{
HENTA FUGARASTI, MUZZAZINAH", MURNI RAMLI \\ Graduate Progam in Biology Education, Universitas Sebelas Maret. Jl. Ir. Sutami No. 36A, Surakarta 57126, Central Java, Indonesia. \\ Tel./fax.: +62-271-632450, `email: yayin_pbio@fkip.uns.ac.id
}

Manuscript received: 14 July 2020. Revision accepted: 31 October 2020.

\begin{abstract}
Fugarasti H, Muzzazinah, Ramli M. 2020. Morphoanatomy of three Indigofera species (Leguminosae-Papilionoideae) in Java Indonesia. Biodiversitas 21: 5531-5539. This study aimed to explore the morphological and detailed anatomical features of the stems, leaves, and roots from three Indonesian Indigofera species. Morphological-anatomical studies of three Indonesian Indigofera species were carried out using embedded microscopic preparations. The anatomical characters of the specimens were observed using a compound optical microscope with magnification 40x, 100x, and 400x. The observation showed the anatomical cross-section of $I$. tinctoria stem was rectangular, I. suffruticosa was hexagonal, and I. arrecta was rounded. The tissue structures of Indigofera species, from the outside layer, were the epidermis, thin cortex, secondary phloem (narrow or wide), thick secondary xylem, and conspicuous pith in the middle. Whilst, the corner of I. suffruticosa stem contained thick collenchyma. The vascular bundles were the open collateral. The leaves of Indigofera species are made up of the upper epidermis, mesophyll (palisade parenchyma, spongy parenchyma), and the lower epidermis. The vascular bundles were located in the middle, with five or six segments of the xylem elements and small groups of phloem elements, all in the parallel lines. The primary stele type of the roots is actinostele, cambium activity pushed him aside. The vascular bundle of the roots consisted of a dense and tight secondary xylem composed of thick-walled circular vessels (mostly tightly arranged). Data about the morphoanatomy structure of three Indonesian Indigofera species could complement the novelty of the morpho-anatomy information records obtained by previous researchers.
\end{abstract}

Keywords: Anatomy, Indigofera, Indonesia, morphology

\section{INTRODUCTION}

Indigofera is a genus member of the family Leguminosae-Papilionoideae and is highly diverse, with 700-750 species, and ranked third as the most diverse genus among Leguminosae (Tamilselvi et al. 2011). There are commonly found in various tropical and subtropical regions (Schrire et al. 2009; Soladoye et al. 2010; Zhao and Gao 2015), are annuals or perennials, and habit varies (Zhao et al. 2016). They can be found as low-growing herbs, shrubs, or small trees up to 1.5-3.0 $\mathrm{m}$ in height (Rzedowski and Grether 2018; Marquiafável et al. 2009), and with small flowers in axillary racemes (Adema 2011), compound leaves (imparipinnate), and cylindrical pods. This plant has great potency for economic and ecological purposes. It has a variety of uses, such as livestock fodder, ornamental plants, medicine, and textile dyes (Tamilselvi et al. 2011).

The highest Indigofera diversity is found in Africa and Madagascar (550 species), Asia (150 species), and Australia (50 species) (Schrire et al. 2009). Among species of Asia, 18 species have been found in Indonesia (de Kort and Thijsse 1984). The latest study describes well-known nine Indigofera species in Java and Madura, four species of which were used as sources of indigo dyes, i.e.: Indigofera. arrecta, I. longiracemosa, I. suffruticosa, and I. tinctoria (Muzzazinah et al. 2016). Indigo dye is famous for the natural blue colors obtained from the leaflets and branches (Soladoye et al. 2010). The dye which is among the most widely used natural dye in the world is obtained mainly from the leaves extraction through a process of fermentation (Leite et al. 2009; Pawade1 and Chinchamalatpure 2020). It is also found, that as the coloring agent for traditional textiles, I. tinctoria found in Java, Madura, and Flores showed different morphological characters that affected the hue and saturation of indigo color on the fabrics (Muzzazinah et al. 2018).

Some Indigofera species are strikingly similar morphologically, thus making it difficult to classify them if relying only on their morphological features. In this context, anatomical studies are related to the structure, contents, and development of cells and tissues (Tamilselvi et al. 2011). These studies can be used to identify and provide additional data for two or more taxa that have high morphological similarities. Moreover, Simpson (2006) stated that anatomical studies support other research in plant science, such as morphogenesis, physiology, ecology, taxonomy, evolution, genetics, and reproduction. Anatomical studies are also used in taxonomy and systematics to assist with species identification by placing the anomalous groups in the right taxonomic levels and show the patterns of relationships been observed in superficial convergence in morphological studies (Nwachukwu et al. 2016).

Information about the anatomy of Indigoferas is still uncommon worldwide (Lievens 1992; Nwachukwu and Mbagwu 2006; Nwachukwu and Mbagwu 2007; Tamilselvi et al. 2011; Paulino et al. 2011; Ghosh et al. 2016; Nwachukwu et al. 2017). There are no significant studies 
on the anatomy of Indigofera species in Indonesia. Three species (I. tinctoria, I. suffruticosa, and I. arrecta) were selected in this research because of their availability. These three have potency as natural dyes, and I. tinctoria has been widely used to produce blue dyes for batik-a traditional clothes in Java and other traditional textiles of Madura and Flores (Muzzazinah et al. 2016).

The stem and leaf anatomy can uncover many characteristics of the species and proved to be important in classification (Lu et al. 2008) and has been widely used in taxonomic research and systematic studies (Noman et al. 2014). Tamilselvi et al. (2011) stated that anatomical systematics is aimed at structures related to vegetative organs (stems, leaves, and roots) for plant classification.

Considering their morphological similarities and the lack of comparative anatomy studies that have been conducted on Indonesian Indigofera species, this study aimed to explore the morphological and detailed anatomical features of the stems, leaves, and roots from three Indonesian Indigofera species, especially the Javanese Indigofera.

\section{MATERIALS AND METHODS}

\section{Study area}

The seeds of three Indigofera species (I. tinctoria, I. arrecta, I. suffruticosa) were prepared and planted in Klaten District, Central Java, Indonesia, which has a tropical climate. Planted at $130 \mathrm{mdpl}$ (meter above sea level) used to grow the Indigofera samples. The above three planting species were treated similarly.

\section{Procedures}

Three Indigofera species (I. tinctoria, I. suffruticosa, and $I$. arrecta) were germinated from seed, and grown until mature fruit had formed. Thirty (30) Indigofera plants were used in this experiment. Samples were taken from 4 sides: north, south, west, and east, then randomized the samples. Root, stem, and leaf samples of each species were harvested from live plants. Stem samples were taken about $30 \mathrm{~cm}$ from the tip of the flowering plant, leaf samples were taken from twigs between 2-5 numbers of the plant, while the root samples used were taken from plant roots that were around 2-3 months old, and taken to the Central Laboratory Unit of Sebelas Maret University (UNS), Surakarta, Indonesia to observe their anatomical structure Observations on the anatomical structures were preceded by the production of embedded microscopic preparations using the Paraffin method adopted from Johansen (1940).

The cleaned specimens were cut transversely to the length of $2 \mathrm{~cm}$. The specimens were submerged into flacons containing FAA solution (1:1:18 formaldehyde $70 \%$, glacial acetic acid 40\%, 70\% alcohol) for 24 hours. Then the specimens were rinsed with a series of alcohols $(70 \%, 80 \%, 95 \%$, and $100 \%)$ for 30 minutes each, then dealcoholized using a series of alcohol/xylol solution (3:1, $1: 1$, and 1:3), pure xylol I, and pure xylol II, each for 30 minutes. The pure xylol solution was replaced with a mixture of xylol/paraffin (1:9) and heated to $57{ }^{\circ} \mathrm{C}$ for 24 hours. Next, the xylol/paraffin mixture (1:9) was replaced with pure paraffin and heated to $57{ }^{\circ} \mathrm{C}$ for 24 hours. Pure paraffin was replaced with new paraffin and soaked for an hour. Specimens were inserted into the paraffin and hardened into blocks. The hardened paraffin blocks were sliced using a rotary microtome with 8-12 micrometers thickness. The sliced paraffin ribbons were glued to the object-glass smeared with a mixture of glycerine and albumin. The object-glass was placed on a hot plate and heated to $45^{\circ} \mathrm{C}$ until the paraffin tape was stretched.

Staining was done by dipping the object-glass into the succession of solutions safranin $1 \%$ in $70 \%$ alcohol (24 hours), and fast green $1 \%$ in ethanol $95 \%$ (30 seconds). The last step was mounting in the deg-glass with Canada balsam (Johansen 1940). The dyed specimen was then labeled and observed with a compound optical microscope.

\section{Data analysis}

The morphological and anatomical data were described, photographed, tabulated, and presented in table 1-4 and figure 1-5. The images were analyzed using Image Raster 3.0, including the thickness of epidermal tissue, cortex, palisade, sponge, phloem, xylem, and pith. All of these data were then descriptively analyzed.

\section{RESULTS AND DISCUSSION}

Indigofera species is a dicotyledonous plant. It has a taproot with white nodules on its roots and has fruit with the pod type which characterizes the Leguminosae. They can be found as herbs, shrubs, or trees with a height of approximately 1-4 meters (Figure 1). The stems of $I$. arrecta are erect (Figure 1C), while in I. tinctoria, and $I$. suffruticosa the branches are more spreading (Figures 1.A, 1.B.). I. suffruticosa has a greenish-colored stem when young Figure 1.B).

The leaves are oval, compound, alternating, having odd leaflet, with each leaflet sits in a line arranged into the oddpinnate position. I. tinctoria leaves have a darker green hue (Figure 1A) than I. suffruticosa and I. arrecta (Figure 1B., 1C.). The lamina of $I$. suffruticosa leaves was thinner and wider (Figure 1B, 2B), while the leaf blade of I. arrecta was thicker and narrower (Figures 1.C, 2.C).

The flowers are complete, zygomorphic, irregular, bisexual, hypogynous, and pedicellate, sepals 5, gamosepalous in all the three species. The flowers were arranged in axillary racemes, and the sepals were fivejagged bell in shape. The petals are butterfly-shaped (Figure 2. D-F). They have pod-type fruit that is relatively thin- to thick-walled, ribbon-shaped, straight, or curved. The pods of I. tinctoria were straight, long, and slender, brown colored with a smooth surface, and slightly curved at the tip. I. arrecta has straight, short, and stubby pods with dark brown colored, whilst I. suffruticosa is the most different type, with short and strongly curved pods, deep brown colored with the densely hairy surface, dehiscent in the suture (Figure 2. B, G). The current morphological features on length and curvature of the pod were also similar to others (Khan et al. 2008; Sanjappa 1985). 

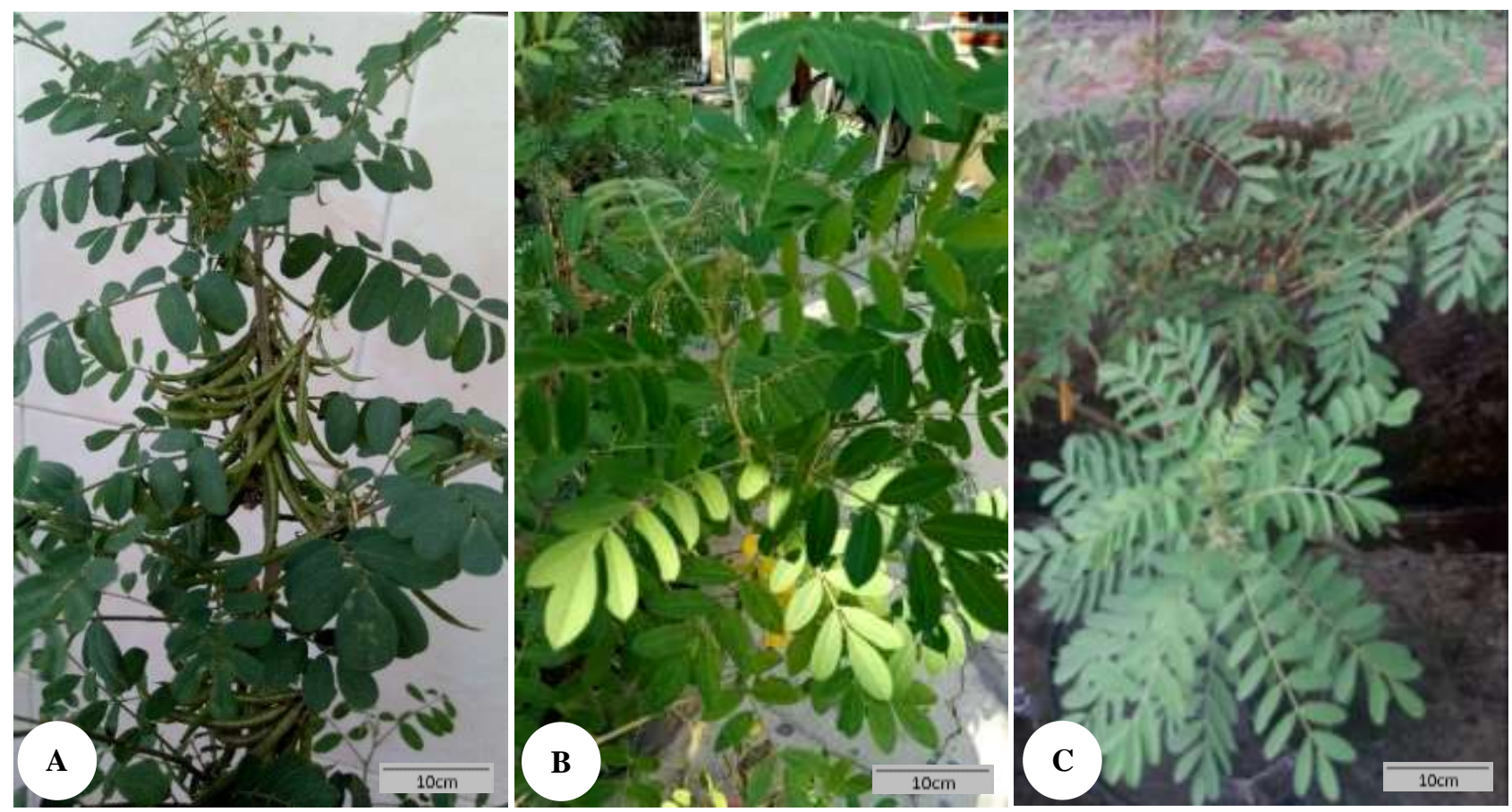

Figure 1. Habit of: A. Indigofera tinctoria; B. I. suffruticosa; and C. I. arrecta
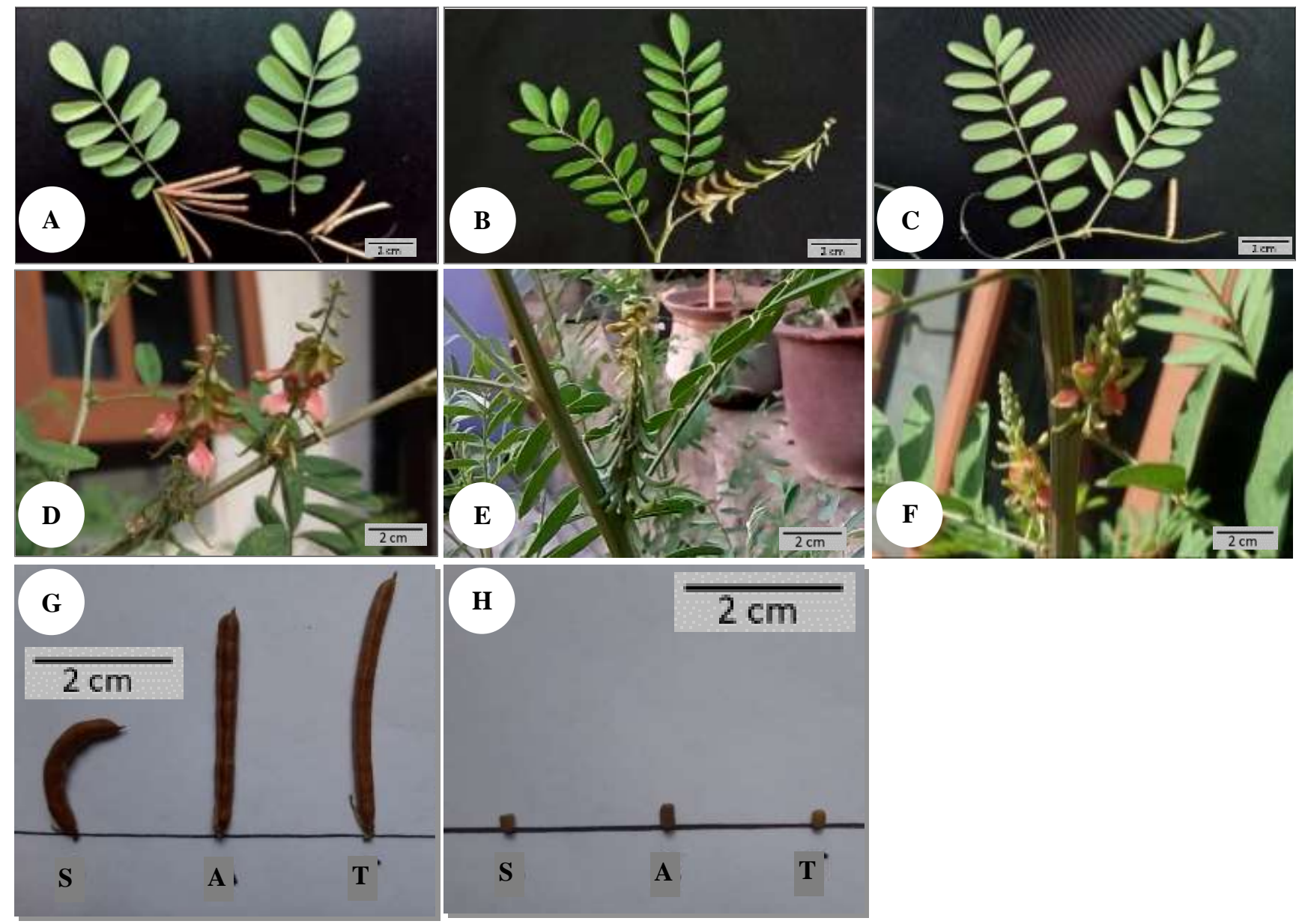

Figure 2. Leaves of: A. Indigofera tinctoria; B. I. suffruticosa; and C. I. arrecta. Flowers of: D. I. tinctoria; E. I. suffruticosa; and F. I. arrecta, G. pod, H. Seeds (S: suffruticosa, A: arrecta, T: tinctoria) 
The pods varied 1-3.5 $\mathrm{cm}$ in length, with 3-11 round or oblong seeds (Figure 2. G-H), conspicuous hilum. The seeds color is oily/dark green in I. tinctoria, dark brown in I. suffruticosa, and black color in I. arrecta (Figure 2. H). The seeds are small around 1-3,5 mm, in shape cube, cuboid, or cylindrical. The color of the seeds is dark green to brownish-black. This is supported by research Teixeira and Correa (2007), which shows that Indigofera species. seeds are mostly rhomboid (rhomboid) but sometimes cube or cylindrical, bright green to brownish-black. The seed color is also used to distinguish species from other taxa investigated where there are more than one species for each color, including $I$. arrecta, and I. tinctoria (Al-Ghamdi 2011). The pod-type fruit and seed morphological characters helped distinguish various Indigofera species. Chauhan and Pandey (2014), said that pod morphology in Indigofera is variable, and the character has little diagnostic value at the generic level. The macroscopic characters are useful in the quick identification of plant material and also serve as an essential criterion (Aguoru and Okoli 2012)(Geetha et al. 2016).

\section{Stem anatomy}

The stem of the studied Indigofera species was composed of epidermis, a thin cortex (parenchyma and collenchyma), narrow or wide secondary phloem, thick secondary xylem, and prominent pith in the middle. $I$. suffruticosa has thick collenchyma at the corners of the trunk (Figure 3.B1, 3.B2, 3.B3). Secondary xylem consisted of 2-8 thin lines of vessel elements, each row was separated by a wide gap. The vessels are small to mediumsized around 14-40 $\mu \mathrm{m}$, thin-walled, round, oval to elliptical (Figure 3.A3-D3).

The cross-sectional structures showed the variation between the three investigated species. The stem of $I$. tinctoria was square or rectangular (Figure 3. A1), I. suffruticosa was hexagonal (Figure 3.B1), while I. arrecta has a rounded stem (Figure 3.C1).

The stem epidermis was multiseriate, consisted of small thick-walled spindle-shaped cells (Nwachukwu et al. 2017). Under the epidermis, one or two layers of collenchyma were present, followed by several layers of parenchyma, each with a width of three or four cells. According to Nwachukwu et al. (2017), the hypodermal layer in I. tinctoria consisted of three to five layers of lignified cells. In I. suffruticosa, the corners of the stem contain thick collenchyma (Figure 3.B1-B3, Table 2), which distinguishes it markedly from other species. The anatomical appearance of the stem can be a distinguishing feature because there is marked variation in the thickness of the layers between different species (Aguoru and Okoli 2012).

Table 1. Morphological comparison of Indigofera tinctoria, I. suffruticosa, I. arrecta

\begin{tabular}{llll}
\hline Characters & I. tinctoria & I. suffruticosa & I. arrecta \\
\hline Stem & Slender and branched & Slender, erect, and branched & Slender, erect, and branched \\
Color of steam & Deep green & Green & Green \\
Type of leaf & Imparipinnate & Imparipinnate & Imparipinnate \\
Number of leaf & 5-11 leaflets per leaf & $9-17$ leaflets per leaf & 5-15 leaflets per leaf \\
Shaped of leaf & Obovate & Obovate oblong & Obovate oblong \\
Color of leaf & Dark green & Light green & Dark green \\
Color of root & Brown & Brown & Brown \\
Flower & Axillary & Axillary & Axillary \\
Color of corola & Pink- orange & Pink-orange & Pink-orange \\
Shaped of pod & Straight, long, and slender & Short and strongly curved & Straight, short and stubby \\
Size of pod & $2,2-3,3$ cm & $1,1-1,4$ cm & $1,8-2,8 \mathrm{~cm}$ \\
Number of seeds & 6-11 seeds & $3-8$ seeds & $4-7$ seeds \\
Size of seed & $1-1,5$ mm & 1,5 mm & $1,5-3,5$ mm \\
Shaped of seed & Cylindrical & $4-$ angled or cube & $4-$ angled or cuboid \\
Color of seed & Dark yellow - bright green - dark brown & Dark green - dark brown - brownish black Reddish-brown- dark brown \\
\hline
\end{tabular}

Table 2. The stem characteristics and cell sizes in the Indigofera sp. stem tissues $(\mu \mathrm{m})$

\begin{tabular}{llll}
\hline Characters & I. tinctoria & I. suffruticosa & I. arrecta \\
\hline Shapes & Rectangular & Hexagonal & Rounded \\
Epidermis & 16.21 & 23.33 & 17.32 \\
Cortex (collenchyma) & 31.35 & 60.47, & 35.59 \\
& & The corner: 134.62 & 54.14 \\
Phloem & 39.49 & $88.59 ; 65.27$ & 188.669 \\
Xylem & 132.25 & 224.04 & 864.754 \\
Pith & 479.90 & 1020.52 & \\
\hline
\end{tabular}



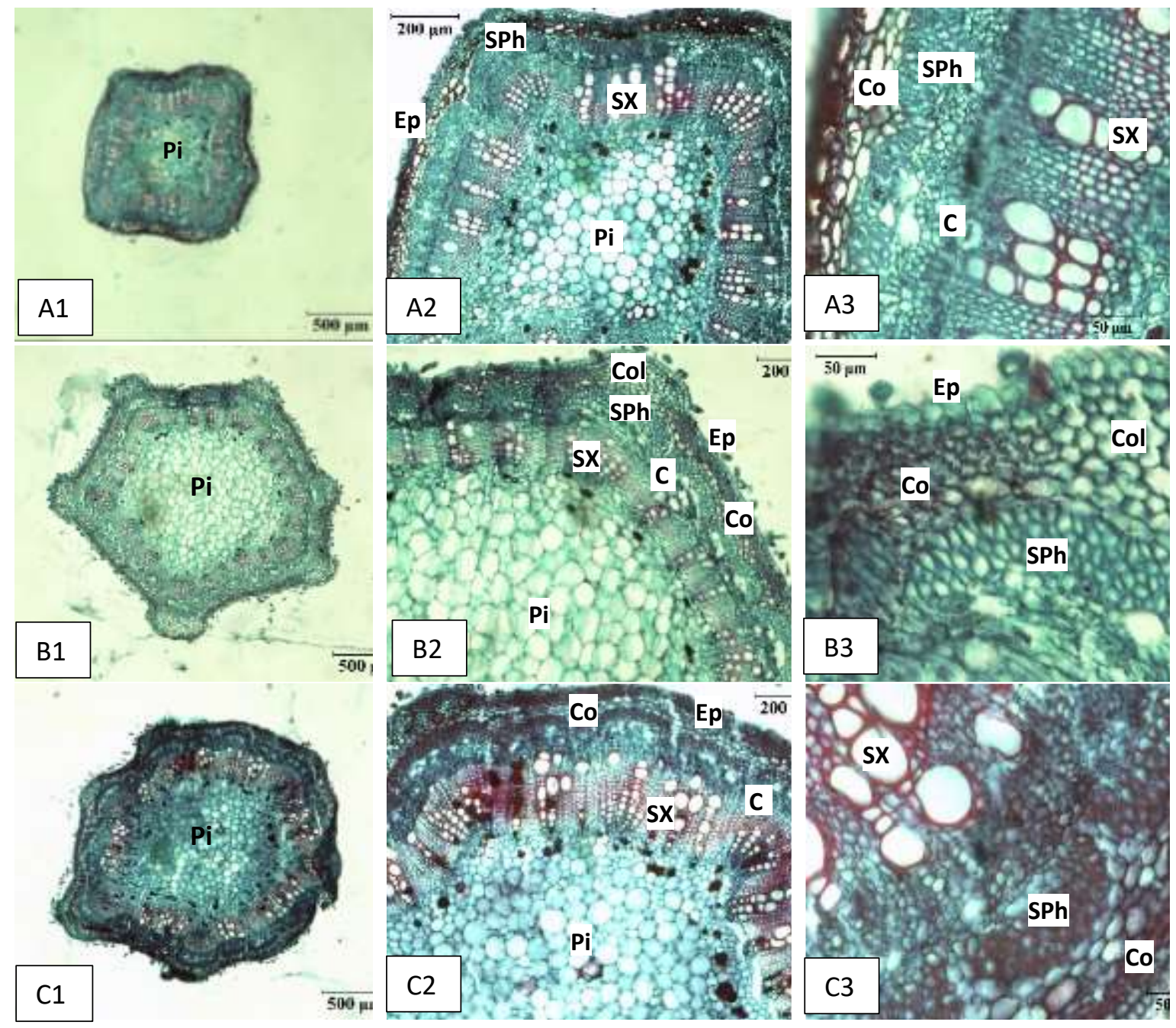

Figure 3. Stem anatomy of: A. Indigofera tinctoria; B. I. suffruticosa; and C. I. arrecta (A1-C1 Magnification: 40x), (A2-C2 M: 100x), (A3-C3 M: 400x). Ep: Epidermis; Co: Cortex; Col: Collenchyma; SPh: Secondary Phloem; SX: Secondary Xylem; Pi: Pith.

The vascular bundles in Indigofera species were arranged in open collateral. The vascular bundles consisted of the narrow outer part of the phloem and followed by a thick xylem cylinder. The phloem elements were arranged in short thin compact rows, while the xylem elements were composed of thick-walled xylem fibers. Xylem in $I$. suffruticosa was thickest compared to the three other species.

\section{Leaf anatomy}

The leaf anatomical structures of the three species were almost identical. The tissues were arranged from outside to inside with the following order: the upper epidermis, mesophyll (palisade parenchyma, spongy parenchyma), and lower epidermis. The Indigofera vascular bundle is in the middle. The vascular bundle consists of three or four parallel lines of xylem elements and a small group of phloem elements.
The leaf epidermis of the three Indigofera species consists of a single layer of cells in the shape of a cuboid, rectangular or hexagonal. There were no trichomes in all three species. Anatomical leaf epidermis is beneficial for systematics, although environmental factors sometimes influence it and generally, does not show high differences in species within the same genus (Dickison 2000).

Mesophyll was divided into adaxial zones composed of circular palisade cells, and abaxial zones composed of spongy parenchyma cells. Nwachukwu and Mbagwu (2006) also found I. tinctoria mesophyll has four to five layers of cells. The palisade cells were narrow, cylindrical, and neatly arranged into two rows. The spongy parenchyma cells were rounded and loosely arranged into three rows. In I. tinctoria, the thickest sponge parenchyma was $33.87 \mu \mathrm{ms}$ (Figure 4. A1; Table 3). I. suffruticosa has a denser palisade parenchymal arrangement (Figure 4.B1). And I. arrecta has an identical structure as I. tinctoria. 

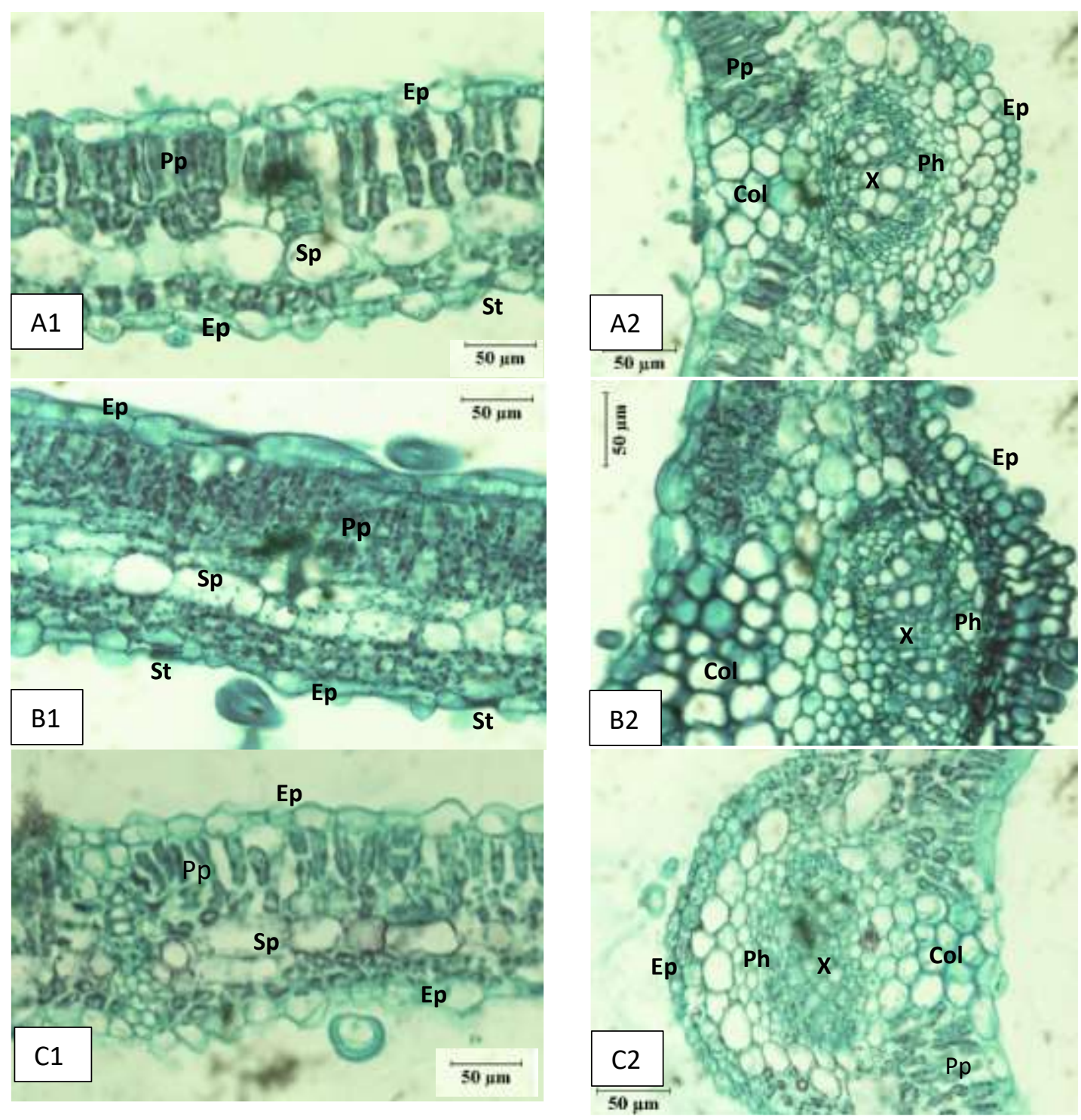

Figure 4. Leaf anatomy of: A. Indigofera tinctoria; B. I. suffruticosa; and C. I. arrecta (A1-C1 Cross-section of the leaf); (A2-C2 Cross-section of the leaf vein). Ep: Epidermis; Pp: Palisade Parenchyma; Col: Collenchyma; Sp: Sponge Parenchyma; X: Xylem; Ph: Phloem

Table 3. The characteristics of cells in the Indigofera sp. leaves tissues $(\mu \mathrm{m})$

\begin{tabular}{llll}
\hline Tissues & I. tinctoria & I. suffruticosa & I. arrecta \\
\hline Upper epidermis & 13.37 & 14.76 & 12.85 \\
Palisade & 42.48 & 50.78 & 32.43 \\
Spongy mesophyll & 33.87 & 33.68 & 29.55 \\
Xylem & 54.55 & 48.61 & 55.56 \\
Phloem & 17.85 & 33.09 & 20.42 \\
Lower epidermis & 11.15 & 11.12 & 10.36 \\
\hline
\end{tabular}

Indigofera has a bond of vessels consisting of xylem and phloem to form a collateral (Amphicribal) in the form of a small circle located in the middle of the leaf. The vascular bundle consists of five or six segments, with
Table 4. The characteristics of cells in the Indigofera sp. root tissues $(\mu \mathrm{m})$

\begin{tabular}{llll}
\hline Tissues & I. tinctoria & I. suffruticosa & I. arrecta \\
\hline Epidermis & 13.20 & 10.77 & 11.51 \\
Cortex & 81.25 & 99.52 & 86.44 \\
Endodermis & 64.78 & 38.67 & 51.39 \\
Xylem & 265.24 & 264.48 & 300.25 \\
Phloem & Divergent & Divergent & Divergent \\
\hline
\end{tabular}

parallel lines of the xylem elements and small groups of phloem elements. The abaxial epidermis is composed of papillae cells. The arrangement of blood vessels of the three species is almost the same (Figures 4.A2-C2). 


\section{Root anatomy}

The root anatomical structures of the three species were identical. The root structure showed the dense, very compact secondary xylem comprised by the thick-walled circular vessel (tightly arranged) in connective tissue (Figure 5).

The tissues were arranged from the outside-in the following order: epidermis, cortex (sclerenchyma, parenchyma), endodermis, phloem, and xylem. Periderm was present to substitute the damaged epidermis due to secondary growth. The periderm was wide with narrow gaps. Periderm was followed by sclerenchyma cells accompanied by thick parenchyma. The secondary phloem was wide and arranged continuously. The secondary xylem was tight and dense. The vascular bundle walls were thick and composed of sclerenchyma. Periderm was arranged in discontinued radial. The primary stele type is usually actinostele. Cambium activity pushed him aside. Radialtype vascular bundles were arranged into fan-shape with $1.5 \mathrm{~mm}$ xylem elements and nine radial bands in each xylem fiber. The xylem is further composed of small units with lignified broad and thick fibers. Lateral xylem was accompanied by small fibers around 20-60 $\mu \mathrm{ms}$.

The differences in the root anatomy structure of the three Indigofera species can be seen in the endodermic tissue. In $I$. arrecta, the endodermic tissue is hexagonal (Figure 5. C1), whereas in I. tinctoria and I. suffruticosa the endodermic tissue is spherical (Figure 5. A1, B1). The systematic value of root anatomical characters can also be seen in the contribution of (Nwachukwu et al. 2016) to the roots of several Indigofera species.
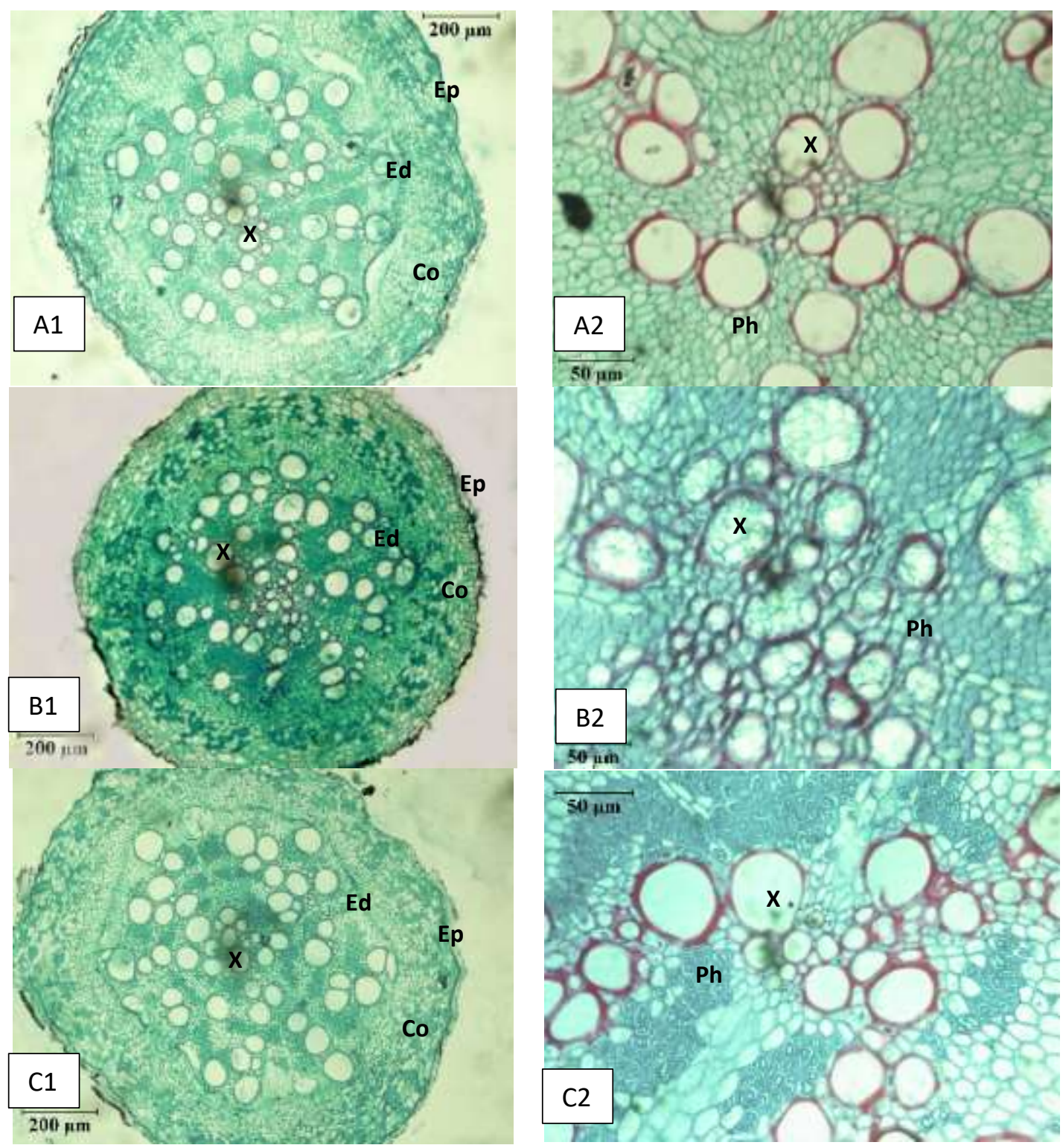

Figure 5. Root anatomy of: A. Indigofera tinctoria; B. I. suffruticosa; and C. I. arrecta. (A1-C1 Magnification: 100x), (A2-C2 M: 400x). Ep: Epidermis; Co: Cortex; Ed: Endodermis; Ph: Phloem, X: Xylem 
In conclusion, morphological and anatomical study of the three Indigofera species showed variations in the tissue forms, colors, and sizes. Those three species have striking identical morphologies, only have minor differences in the leaf's colors and pod shapes. The pods of I. tinctoria were straight, long, and slender, I. arrecta has straight, short, and stubby pods, whilst $I$. suffruticosa is the most different type, with short and curved pods. The anatomical study revealed $I$. tinctoria has rectangular stem cross-section, $I$. suffruticosa was hexagonal, and I. arrecta has rounded one. The stems were composed of various tissues in the following succession: epidermis, thin cortex, thin or thick secondary phloem, thick secondary xylem, and prominent pith. I. suffruticosa has corners on it stems with thick collenchyma that differentiates it from other species. The leaf was composed of the upper epidermis, mesophyll (palisade parenchyma, sponge parenchyma), and lower epidermis. The vascular bundles were located in the middle, with five or six segments of the xylem elements and small groups of phloem elements, all in the parallel lines. The root anatomy showed dense secondary xylem. The secondary xylem was composed of thick-walled vessel elements, endodermis tissue in I. arrecta was hexagonal.

The results of this study provide additional information regarding the morphological and anatomical characteristics of Indigofera which can be used as additional data for identification, characteristics, and classification.tasks, and also could complement the novelty of the morfoanatomy information records obtained by previous researchers. Researchers also recommend conducting similar research not limited to the three Indigofera species but with other Indigofera species in greater numbers so that the information obtained is more complete.

\section{ACKNOWLEDGEMENTS}

This research was sponsored by the Grant for Postgraduate Research, Universitas Sebelas Maret, Indonesia, Year 2018-2019, No. 516/UN27.21/PP/2019.

\section{REFERENCES}

Adema F. 2011. Notes on Malesian Fabaceae (LeguminosaePapilionoideae) 15. notes on Indigofera. Blumea: J Plant Taxon Plant Geograph 270-272.

Aguoru CU, Okoli BE. 2012. Comparative stem and petiole anatomy of West African species of Momordica L (Cucurbitaceae ). Afr J Plant Sci 6 (December): 403-409. DOI: 10.5897/AJPS11.309.

Al-Ghamdi FA. 2011. Seed morphology of some species of Indigofera (Fabaceae) from Saudi Arabia (identification of species and systematic significance). Am J Plant Sci 2: 484-495. DOI: 10.4236/ajps.2011.23057.

Pawade1 PN, Chinchamalatpure KP. 2020. Morpho-anatomical studies of Indigofera Linnaei. IJCIRAS 1 (5). DOI: 10.13140/RG.2.2.30985.39522.

Chauhan V, Arun KP. 2014. Structure and evolution of the pod in Indigofera (Fabaceae) reveals a trend towards small thin indehiscent pods. Bot J Linn Soc 176 (2): 260-276. DOI: 10.1111/boj.12203.

de Kort I, Thijsse G. 1984. A revision of the genus Indigofera (Leguminosae-Papilionoideae) in Southeast Asia. Blumea 30: 89-151.

Dickison WC. 2000. Integrative Plant Anatomy. Elsevier, Amsterdam.
Geetha DH, Indhiramuthu J, Rajeswari M. 2016. Micro-morphological and phytochemical studies of aerial parts of Indigofera enneaphylla Linn. J Pharmacog Phytochem 5 (1): 216-220.

Ghosh B, Tanmoy M, Asok G, Animesh KD, Ankita P. 2016. Taxonomical, anatomical, cytological and palynological assessment of a germplasm of Indigofera tinctoria L. (Fabaceae): An Ayurvedic plant. Int J Res Ayurveda Pharm 7 (Suppl 4): 90-95. DOI: 10.7897/2277-4343.075227.

Johansen DA. 1940. Plant-Microtechnique. First. McGraw-Hill Book Company, New York and London

Khan ABMMM, Howlader MHK, Prodhan AKMA, Rahman MM, Fakir MSA. 2008. Morphological variation in three Indigofera spp. J Agrofor Environ 2 (1): 1-6.

Leite VG, Flávia SM, Daniela de PM, Simone de PT. 2009. Fruit anatomy of neotropical species of Indigofera (Leguminosae, Papilionoideae) with functional and taxonomic implications 1. J Torrey Bot Soc 136 (2): 203-211. DOI: 10.3159/08-RA-106.1.

Lievens AW. 1992. Taxonomic treatment of Indigofera L. (Fabaceae: Faboideae) in the New World. [Dissertations]. LSU, Sweden.

Lu HF, Jiang B, Shen ZG, Shen JB, Peng QF, Cheng CG. 2008. Comparative leaf anatomy, FTIR discrimination and biogeographical analysis of Camellia section Tuberculata (Theaceae) with a discussion of its taxonomic treatments. Plant Syst Evol 274: 223-235. DOI: 10.1007/s00606-008-0047-6.

Marquiafável FS, Maria DSF, Simone de PT. 2009. Novel reports of glands in neotropical species of Indigofera L. (Leguminosae, Papilionoideae). Flora: Morph Distrib Funct Ecol Plants 204 (3): 189197. DOI: 10.1016/j.flora.2008.01.012.

Muzzazinah, Chikmawati T, Ariyanti NS. 2016. Correlation of morphological characteristics with the presence of indicant in Indigofera sp. dyestuff. Sains Malaysiana 45 (6): 883-890.

Muzzazinah, Chikmawati T, Ariyanti NS, Ramli M, Nurmiyati. 2018. Morphological characterization of dye producing Tom Java (Indigofera tinctoria L.) in three islands of Indonesia. Malays Appl Biol 47: 91-99.

Noman A, Qasim A, Mansoor H, Tahir M, Tehreema I. 2014. Comparison of leaf anatomical characteristics of Hibiscus rosa-sinensis grown in Faisalabad region. Pak J Bot 46 (1): 199-206.

Nwachukwu CU, Edeoga HO, Kemka-Evans CI. 2017. Stem anatomical studies of some species of Indigofera. Intl Res J Plant Crop Sci 3 (1): 24-25.

Nwachukwu CU, Edeoga HO, Kemka-Evans CI, Iwuanyanwu CJ. 2016. Stem anatomical studies of some species of Indigofera L. (Leguminosae- Papilionoideae). J Adv Biol 9 (November): 19671971 .

Nwachukwu CU, Mbagwu FN. 2006. Anatomical studies on the petiole of some species of Indigofera. Agric J 1 (2): 55-58.

Nwachukwu CU, Mbagwu FN. 2007. 154 leaf anatomy of eight species of Indigofera L. Agric J 2 (1): 149-154.

Paulino JV, Milton G, Simone de PT. 2011. Floral developmental morphology of three Indigofera species (Leguminosae) and its systematic significance within Papilionoideae. Plant Syst Evol 292: 165-176. DOI: 10.1007/s00606-010-0405-z.

Rzedowski J, Rosaura G. 2018. Two new species of the genus Indigofera (Papilionoideae, Leguminosae) from Central Mexico. Phytotaxa 372 (4): 256-262.

Sanjappa M. 1985. The Genus Indigofera L. (Fabaceae-Papilionoideae) in Burma. Reinwardtia, Bogor

Schrire BD, Lavin M, Nigel P, Félix F. 2009. Phylogeny of the tribe Indigofereae (Leguminosae-Papilionoideae): geographically structured more in succulent-rich and temperate settings than in grassrich environments. Am J Bot 96 (4): 816-52. DOI: 10.3732/ajb.0800185

Simpson MG. 2006. Plant Systematics. Academic Press, New York.

Soladoye MO, Sonibare MA, Chukwuma EC. 2010. Morphometric study of the genus Indigofera Linn. (Leguminosae-Papilionoideae) in South-Western Nigeria. Int $\mathrm{J}$ Bot 6 (3): 343-50. DOI: 10.3923/ijb.2010.343.350

Tamilselvi N, Dhamotharan R, Krishnamoorthy P, Shivakumar. 2011. Anatomical studies of Indigofera aspalathoides Vahl (Fabaceae). J Chemi Pharm Res 3 (2): 738-746.

Teixeira SP, Vani MAC. 2007. Morfo-anatomia do envoltorio seminal de especies Brasileiras de Indigofera L (Leguminosae, Papilionoideae). Rodriguésia 58 (2): 265-273. 
Zhao XL, Gao XF. 2015. Indigofera pseudonigrescens (Fabaceae: Papilionoideae): A new species from Sichuan, China. Phytotaxa 222 (4): 251-258. DOI: 10.11646/phytotaxa.222.4.2.
Zhao XL, Gao XF, Xu B. 2016. Pollen morphology of Indigofera (Fabaceae) in China and its taxonomic implications. Plant Syst Evol 302 (4): 469-479. DOI: 10.1007/s00606-015-1275-1. 